\title{
Communication
}

[Comunicação]

\section{Establishing the hypoosmotic swelling test for sperm analysis in collared peccaries (Pecari tajacu)}

[Estabelecimento do teste hiposmótico para a análise de sêmen de catetos (Pecari tajacu)]

\author{
E.A.A. Santos, P.C. Sousa, G.C.X. Peixoto, B.R. Simão, M.F. Oliveira, A.R. Silva*
}

Universidade Federal Rural do Semi-Árido - UFERSA - Mossoró, RN

It is necessary to be aware of the reproductive aspects of the collared peccaries (Pecari tajacu) when aiming for its multiplication under captivity. Until this moment, semen analysis in such species has been mainly based on the evaluation of classic parameters (Costa and Paula 2005; Souza et al., 2009). The hypoosmotic swelling (HOS) test was only empirically applied using distilled water as a hypoosmotic solution (Souza et al., 2009; Castelo et al., 2010).

First described in humans (Jeyendran et al., 1984), the HOS test identifies sperm with functional intact membranes. For application in different species, it is necessary to determine the specific osmolarity of solutions that are to be used in the test regarding the species being evaluated. In swine, the domestic animal that is closely related to the peccaries, solutions varying from 50 to $150 \mathrm{mOsm} / \mathrm{L}$ have been reported (Vazquez et al., 1997). Furthermore, the use of distilled water as a hypoosmotic solution (0 $\mathrm{mOsm} / \mathrm{L}$ ) has been illustrated for the test in stallions (Dell'Aqua et al., 2002) and $\operatorname{dogs}$ (Quintela et al., 2010).

The present study aims to establish a suitable hypoosmotic solution that causes the maximum number of identifiable swollen cells in order to validate the HOS test for the sperm membrane functional analysis in collared peccary semen.

A total of 13 mature male collared peccaries $(40.7 \pm 1.6$ months of age and $22.5 \pm 2.8 \mathrm{~kg}$ of weight) were used. The animals belonged to the Centre of Multiplication of Wild Animals -

Recebido em 10 de julho de 2012

Aceito em 8 de maio de 2013

* Autor para correspondência (corresponding author)

E-mail: legio2000@yahoo.com
UFERSA (Mossoró, RN, Brazil; 5¹1'17'S, $\left.37^{\circ} 20^{\prime} 39^{\prime \prime} \mathrm{W}\right)$. The animals were isolated from the females and maintained outdoors for a $12 \mathrm{~h}$ natural photoperiod. Sow food and tropical fruits were fed to the animals. Water was provided ad libitum. The experimental protocols were approved by the Ethics committee of UFERSA (Process no 23091.0253/114).

The animals were restrained using a hand net and then anesthetized by intravenous administration of propofol (Propovan®, Cristalia, Fortaleza, Brazil) at $5 \mathrm{mg} / \mathrm{kg}$ in bolus (Souza et al., 2009). The semen was collected using an electroejaculator (Autojac $®$, Neovet, Campinas, $\mathrm{SP}$, Brazil) connected to a $12 \mathrm{~V}$ source, using the protocol previously described for the species (Castelo et al., 2010). Semen was collected in plastic tubes and immediately evaluated for color, $\mathrm{pH}$ and volume. Sperm motility and vigor (0-5) were assessed through light microscopy (x100 and x400). A semen smear stained with brome-phenol blue was used for the analysis of sperm viability and morphology, counting 200 cells under light microscopy. Sperm concentration was determined using a Neubauer chamber.

Semen aliquots $(10 \mu \mathrm{L})$ were added to $90 \mu \mathrm{L}$ of various hypoosmotic solutions and incubated for $40 \mathrm{~min}$ at $37^{\circ} \mathrm{C}$. For this purpose, distilled water $(0 \mathrm{mOsm} / \mathrm{L})$ and fructose solutions $(50,100,150$ and $200 \mathrm{mOsm} / \mathrm{L}$ ) were used. After incubation, evaluations were conducted under phase contrast microscopy (x1000). A total of 200 sperm were counted in at least five fields and classified as reactive or non-reactive based on the presence or 
absence of coiled (swelled) tails, respectively (Jeyendran et al., 1984). The percentage of sperm with tail defects (based on sperm morphology evaluation) was subtracted from the percentage of reactive sperm.

The results were expressed as mean \pm SEM, and analyzed by the Statistical Analysis System (SAS 6.10, SAS Institute Inc., Cary, NC, USA). Data were checked for normality by Cramer-von Mises test, and were square-root transformed. Then the data were evaluated by ANOVA followed by the Tukey test $(\mathrm{P}<0.05)$ for comparisons among hypoosmotic solutions. Correlations among functional membrane integrity and other sperm parameters were analyzed by Spearman's correlation test $(\mathrm{P}<0.05)$.
A total of 13 ejaculates were obtained from 13 different males, which were white and watery, contained sperm, and had $\mathrm{pH}$ averaging 7.5 \pm 0.9 . The mean $( \pm$ SEM) fresh semen end points were $2 \pm 1.4 \mathrm{~mL}$ for volume, with a concentration of $463.1 \pm 37.5 \times 10^{6} \mathrm{sperm} / \mathrm{mL}, 89.3 \pm 6 \%$ motile sperm with vigor $4.1 \pm 0.7$, viability of $83.9 \pm 10.3 \%$, and $79.1 \pm 10.4 \%$ normal cells.

Regarding the HOS tests, it was verified that as the osmolarity of the medium increased, there was a reduction in the number of reactive sperm (Fig.1). Higher values of reactive sperm were detected in the use of distilled water $(\mathrm{P}<0.05)$, which also presented the lowest variation in the results. No significant correlation to the other sperm characteristics was found in any of the values for reactive sperm for the solutions presented (Tab. 1).

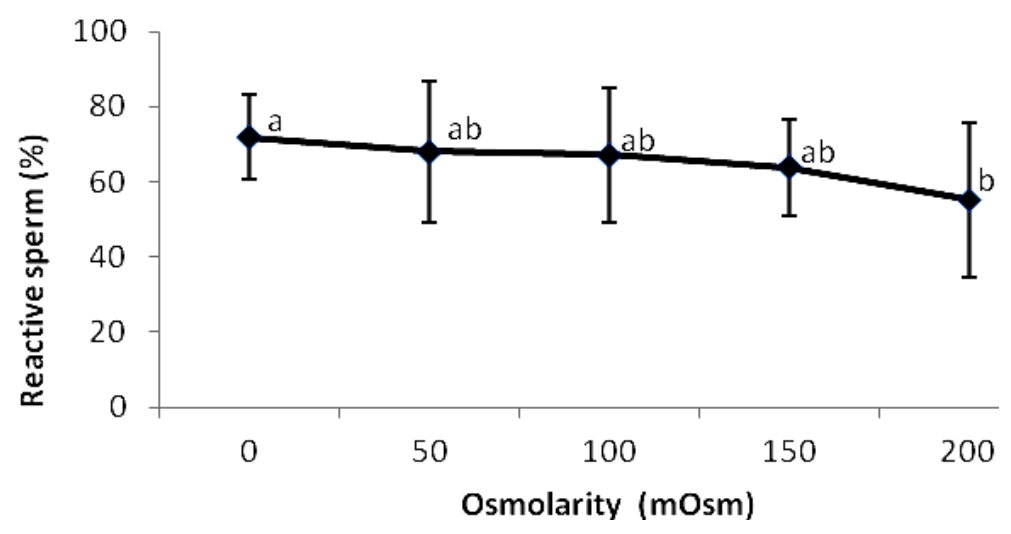

Figure 1. Mean ( \pm SEM) values for collared peccaries' reacted sperm after a hypoosmotic swelling test using solutions with various osmolarities. $\left({ }^{\mathrm{ab}}\right.$ Means without a common superscript differ $-\mathrm{P}<0.05$ ).

Table 1. Spearman correlations $\left(\mathrm{r}^{*}\right)$ between different hypoosmotic solutions and semen characteristics of adult collared peccary

\begin{tabular}{ccccc} 
& $\begin{array}{c}\text { Motility } \\
(\%)\end{array}$ & $\begin{array}{c}\text { Vigor } \\
(0-5)\end{array}$ & $\begin{array}{c}\text { Sperm viability } \\
(\%)\end{array}$ & $\begin{array}{c}\text { Normal morphology } \\
(\%)\end{array}$ \\
\hline 0 mOsm & -0.32 & 0.01 & 0.34 & 0.36 \\
50 mOsm & -0.17 & -0.36 & -0.48 & 0.42 \\
100 mOsm & -0.29 & -0.30 & -0.02 & 0.36 \\
150 mOsm & 0.42 & 0.42 & 0.24 & 0.12 \\
200 mOsm & 0.32 & -0.07 & -0.22 & 0.13 \\
\hline
\end{tabular}

*No significant correlation was verified among parameters $(\mathrm{P}>0.05)$.

In general, the optimal hypoosmotic solution should exert an osmotic stress large enough to cause an observable increase in volume but small enough to prevent lyses of the sperm membrane (Jeyendran et al., 1984). In the present study, the highest proportion of reactive sperm $(71.8 \%)$ was detected for the use of distilled water (0 $\mathrm{mOsm} / \mathrm{L}$ ), which, however, did not differed from the $50-150 \mathrm{mOsm} / \mathrm{mL}$ solutions. This indicates that the collared peccary sperm can be subjected to an osmolarity range broader than the domestic swine in which solutions varying from 50 to 
$150 \mathrm{mOsm} / \mathrm{L}$ have been reported for the HOS test (Vazquez et al., 1997). It is interesting to note that as the osmolarity of the medium increased, there was a linear reduction in the number of reactive sperm in the peccaries. Such results are different from those reported for the swine, which presented maximum values of reactive sperm in the use of a $100 \mathrm{mOsm} / \mathrm{L}$ solution in comparison to 75 or $125 \mathrm{mOsm} / \mathrm{L}$ media (Matson et al., 2009).

It should be mentioned that distilled water presents the advantage of being relatively inexpensive and easier to manipulate in comparison to sugar-based solutions used for the conventional HOS test (Quintela et al., 2010). Additionally, distilled water proved to be more effective than other sugar-based solutions for the detection of the functional integrity of plasma membrane in equines (Dell'Aqua et al., 2002). Thus, it can be explained that the plasma membrane of equine sperm presents high permeability to water, owing to the presence of a porous membrane and protein water channels (Neild et al., 1999). It is thus speculated that these characteristics are also present in the collared peccary sperm, which would facilitate its permeability in water.

Individual variation on the osmotic responses was reported in swine, which is attributed to differences in the composition, functionality, and resistance of the sperm (Pérez-Llano et al., 2001). Moreover, the ion exchange capacity is different among boar ejaculates (Petzoldt, 1996). It is thus hypothesized that there are marked differences related to the sperm structure and function between domestic swine and peccaries. Besides this, an individual variation related to semen parameters among different peccaries and also among different ejaculates from the same individual was recently reported (Peixoto et al., 2012), which could also influence the HOS test results. In spite of this, the lowest variation in results was detected in the use of distilled water.

No correlation among the results derived from HOS test and other classical analyses was verified in peccaries. In fact, Perez-Llano et al. (2001) reported that correlations can exist between HOS test and in vivo fertility in domestic swine, but no relations between HOS test and other semen parameters are demonstrated. In addition, Lechniak et al. (2002) suggested the HOS test as a strong indicative for sperm capacitation ability in vitro. They also emphasize that the viability test only evaluates the membrane structure by analyzing the transport of supravital staining through it; on the other hand, HOS test would be more precise since it evaluates the functionality of the membrane by analyzing the sodium/potassium pump activity, which is important for the regulation of water permeability. In the current literature, however, contradictory data is reported by Smardzija et al. (2008), who reported the existence of correlations between the response of the sperm to the HOS test and the sperm viability in swine. Regardless, the existence of a correlation between HOS test and fertility should be further investigated in collared peccaries.

In conclusion, the HOS test proved to be a suitable technique to evaluate the membrane status of collared peccary sperm. We confirm that distilled water appeared to be an adequate solution for use in the HOS test for fresh sperm, which would facilitate the routine analyses of collared peccary semen.

Keywords: collared peccary, semen, andrology, wild animal

\section{RESUMO}

Soluções hiposmóticas com diferentes concentrações (0, 50,100, 150, 200mOsm/L) foram testadas para a avaliação funcional da membrana espermática de catetos $(n=13)$. Foi verificado que o número de espermatozoides reagidos diminuía $(P<0,05)$ de acordo com o aumento da osmolaridade do meio. A maior porcentagem $(71,8 \%)$ de espermatozoides reagidos, bem como a menor variação nas respostas osmóticas, foi detectada com o uso de água destilada $(0 \mathrm{mOsm} / \mathrm{L})(P<0,05)$, a qual também apresentou a menor variação nos resultados, de acordo com os erros padrão verificados. Em conclusão, a água destilada aparenta ser uma solução adequada para o uso no teste hiposmótico para sêmen de catetos.

Palavras-chave: cateto, sêmen, andrologia, animal silvestre 


\section{REFERENCES}

CASTELO, T.S.; BEZERRA, F.S.B.; SOUZA, A.L.P. et al. Influence of the thawing rate on the cryopreservation of semen from collared peccaries (Tayassu tajacu) using Tris-based extenders. Theriogenology, v.74, p.1060-1065, 2010.

COSTA, D.S.; PAULA, T.A.R. Semen collection and evaluation of the collared peccary (Tayassu tajacu). Biota Neotrop., v.5, p.1-6, 2005.

DELL'AQUA Jr, J.A; PAPA, F.O.; ZAHN, F.S. et al. Novo teste osmótico de avaliação da integridade da membrana plasmática de sêmen congelado eqüino. Rev. Bras. Rep. Anim., v.26, p.189-191, 2002.

JEYENDRAN, R.S.; VAN DER VER, H.H.; PEREZ-PELAEZ, M. et al. Development of an assay to assess the functional integrity of the human sperm membrane and its relationship to other semen characteristics. J. Reprod. Fertil, v.70, p.219-228, 1984.

LECHNIAK, D.; KEDZIERSKI, A.; STANISLAWSKI, D. The use of HOS test to evaluate membrane functionality of boar sperm capacitated in vitro. Reprod. Dom. Anim., v.37, p.379-380, 2002.

MATSON, P; KAPPELLE, W; MALECKI, I. The use of a hypo-osmotic swelling (HOS) test on sperm of the pig (Sus scrofa domesticus), emu (Dromaius novaehollandiae), Asian elephant (Elephas maximus), hamadryas baboon (Papio hamadryas hamadryas), and central rock rat (Zyzomys pedunculatus). Reprod. Biol., v.9, p.181-187, 2009.
NEILD, D.; CHAVES, G.; FLORES, M. et al. Hypoosmotic test in equine spermatozoa. Theriogenology, v.51, p.721-727, 1999.

PEIXOTO, G.C.X.; SILVA, M.A.; CASTELO, T.S. et al. Individual variation related to testicular biometry and semen characteristics in collared peccaries (Tayassu tajacu Linnaeus, 1758). Anim. Reprod. Sci., v.134, p.191-196, 2012.

PÉREZ-LLANO, B.; LORENZO, J.L.; YENES, P. A short hypoosmotic swelling test for the prediction of boar sperm fertility. Theriogenology, v.56, p.387-398, 2001.

PETZOLD, R. Ion movement on the boar sperm membrane during storage. Reprod. Domest. Anim. v.31, p.129-133, 1996.

QUINTELA, A.T.; OLIVEIRA, I.R.S.; SOUZA, A.O. et al. Water-induced hypo-osmotic test for the evaluation of canine sperm membrane integrity. Anim. Reprod., v.7, p.70-74, 2010.

SMARDZIJA, M.; DOBRANIC, T.; KRUSLIN, S. et al. The use of the hypoosmotic swelling test and supravital staining in evaluation of sperm quality in boars. Veterinarski Arrhiv., v.78, p.279-287, 2008.

SOUZA, A.L.P.; CASTELO, T.S.; QUEIROZ, J.P.A.F. et al. Evaluation of anesthetic protocol for the collection of semen from captive collared peccaries (Tayassu tajacu) by eletroejaculation. Anim. Reprod. Sci., v.116, p.370-375, 2009.

VAZQUEZ, J.M.; MARTINEZ, E.A.; MARTINEZ, P. et al. Hypoosmotic swelling of boar spermatozoa compared to other methods for analyzing the sperm membrane. Theriogenology, v.47, p.913$922,1997$. 